九州大学学術情報リポジトリ

Kyushu University Institutional Repository

\title{
A New Eulophid Parasite Of Adris Tyrannus Guenee From Japan (Hym., Eulophidae)
}

Yasumatsu, Keizo

Entomological Laboratory, Department of Agriculture, Kyushu University

https://doi.org/10.5109/22651

出版情報：九州大学大学院農学研究院紀要. 10 (2)，pp. 163-168，1953-09. Kyushu University バージョン：

権利関係 : 
Journal of the Faculty of Agriculture, Kyüshü University, Vol. 10, No. 2

September 30, 1951

\author{
A NEW EULOPHID PARASITE OF ADRIS TYRANNUS \\ GUENEE FROM JAPAN \\ (Hym., Eulophidae) \\ Keizô Yasumatsu
}

The citrus orchards of Japan have long been sustaining attacks by Noctuid moths which have caused comparatively serious damage by piercing the rind of the citrus fruits with their probosces.

While studying the biology of Adris tyrannus Guénée, one of the fruit-piercing Noctuidae, in Miyazaki Prefecture, Kyushu, Mr. S. Nasu found an Eulophid parasitic on the larvae of this moth. Professor S. Nakajima, of the Miyazaki University, handed the specimens of this parasite over to me for identification.

After carefully examining the material submitted to me, I came to the conclusion that the specimens presented a new species. Meanwhile, I sent some specimens of this parasite to Dr. B. D. Burks, Hymenopterist of the U. S. National Museum (to whom I was referred by Mr. Karl V. Krombein) and to Dr. Ch. Ferritre, Hymenopterist of the Geneva Museum, to confirm my conclusion. I further borrowed Girault's type specimens of Euplectrus-species from Dr. G. Mack, Director of the Queensland Museum.

I am deeply indebted to Dr. B. D. Burks for his kindness in comparing specimens under his charge and for his generous criticism to my manuscript. I am also indebted very much to Dr. Ch. Ferrière for his valuable advice and for the donation of valuable reprints, and to Dr. G. Mack for the loan of precious type specimens of Euplectrus under his charge. Further I am indebted for constant guidance and encouragement to Professor T. Esaki; for many favours to Mr. Karl V. Krombein; for literature to Mr. K. Maruyama; and for the donation of specimens to Professor S. Nakajima and Mr. S. Nasu, respectively. 


\section{A Tentative Key to the Species of the Genus EuPLECTRUS SWEDERUS FROM JAPAN ANT) FORMOSA}

1. Head and thorax partly yellow nigromaculatus Ashmead

- Head and thorax black

2. Hind coxae black japonicus Ashmead

- All coxae pale 3

3. Scutellum at base deeply reticulated, apically longitudinally rugose kuwanae Crawford

- Scutellum finely, indistinctly reticulated .............................. 4

4. Clypeal area black .................................................... 5

- Clypeal area pale .................................................... 6

5. First funicle segment not distinctly longer than pedicel koebelei Crawford

- First funicle segment much longer than pedicel ..... taiwanus Sonan

6. Mesoscutum with a complete, longitudinal, median carina noctuidiphagus $\mathrm{n}$. sp.

--.- Mesoscutum without such a median carina. fukaii Crawford

\section{Euplectrus noctuidiphagus n. sp.}

c\%. Head and thorax black, clypeal area whitish; antennae orange-yellow, brownish apically; antennal scape of male pale, pedicel and funicle darker or brownish apically; legs entirely orange-yellow, legs of male much paler; abdomen orange-yellow above and below, black only on the sides and the apical half. Vertex and thorax with some scattered, long, whitish ciliae.

$\because$. Head very transverse, almost smooth; vertex with a fine but distinct carina extending completely across its posterior margin; the lateral ocelli closer to the front ocellus than to the eye margins; eyes large and oval, not ciliate. Antennae with the scape narrow, its apex reaching the level of the front ocellus; scape, pedicel and the first funicle segment of the same width; scape long, about six times as long as wide, pedicel about twice as long as wide at the apex; relative lengths of scape, pedicel and the first funicle segment-65:18:40, the following segments shorter. Pronotum short, with a distinct, transverse carina comparatively far from the posterior margin. Mesonotum irregularly, transversely striate in the middle; mesoscutum with a complete, longitudinal, median carina. Axillae almost smooth. Scutellum 
finely reticulate. Propodeum smooth, shining, with a distinct, complete, median, longitudinal carina and the spiracles distinctly oblong oval. The longest hind tibial spur almost as long as the first two tarsal segments taken together. Wings large; marginal vein slightly longer than the submarginal vein, the costal cell slightly broadened, relative lengths of the stigmal and the postmarginal veins $-5: 9$, marginal vein about four times as long as the stigmal vein. Abdomen broadened behind, triangular, shorter than the thorax; abdominal petiole short, subquadrate or slightly wider than long, shagreened and with a complete, longitudinal, median carina.

3. Similar; relative lengths of the scape, pedicel and the first funicle segment $-50: 15: 40$, scape especially broadened in the middle, less than three times as wide as long, scape much wider than pedicel, pedicel slightly but distinctly longer than wide and very slightly wider than the first funicle segment which is as long as the third one, first funicle segment distinctly longer than the second one which is as long as fourth one. Abdomen much narrower than that of the female, petiole without a longitudinal carina.

Length of body : $\hat{i}$ about $2.0 \mathrm{~mm}$. + about $3.5 \mathrm{~mm}$.

Holotype: ¿, 13. x. 1951, Miyazaki, Kyushu (Mr. S. Nasu), ex a larva of Adris tyrannus Guénée.

Allotype: , 19. x. 1951, the same data as the holotype.

Paratypes: $1588,13$. x. 1951, 13우우, 19. x. 1951.

Holo-, allo- and 20 paratypes are preserved in the collection of the Entomological Laboratory, Kyushu University, Fukuoka. Eight paratypes will be distributed to the British Museum (Natural History), U. S. National Museum, American Museum of Natural History, and the Geneva Museum.

Habitat: Japan.

This new species is somewhat allied to Euplectrus taiwanus Sonan, 1942, from Formosa, but differs from the latter in the following points:-1. clypeal area whitish, 2. head smooth and shining, without any reticulated, impressed lines, 3 . propodeum without a crenulate carina along the basal margin, 4. abdominal petiole without longitudinal striations. Judging from the description, the new species is also related to Euplectrus kuwanae Crawford, 1911, from Japan, the types of which are deposited in the 
U. S. National Museum. Dr. Burks was so kind as to compare my specimen not only with the type of kuwanae but also all the specimens of the other species in his trust and wrote me as follows:- "I have compared it with the type of E. kuwanae and find that it is not that species. I checked it against all the species of this genus in our collection, but I am sorry to say I cannot place it. It is nearest to agaristae Crawford, from Australia, and is also quite close to the cosmopolitan plathypenae Howard, but is not identical with either. It has a complete, longitudinal, median carina on the mesoscutum and there is a fine but clearly discernible carina extending completely across the posterior margin of the vertex. These characters, along with the color, distinguish your specimen from all the species of this genus in our collection" (February 1.5, 1952).

The genus Euplectrus is parasitic on larvae of Lepidoptera. Since no concise world list of the known host Lepidoptera of the genus has been published hitherto, it has been considered appropriate to attempt to summarize the available data regarding the Euplectrus-species that have been recorded from the pests of crops.

A Lis' of Host of EUdplactiad:

\begin{tabular}{lll}
\hline \multicolumn{1}{c}{ Species } & \multicolumn{1}{c}{ Hosts } & Localities \\
\hline agaristae Crawtord & Phalaenoides glycinae Lewin & Australia \\
bicolor Swederus & Amathes c-nigrum Linné & U. S. A. \\
& $\begin{array}{l}\text { Aplecta nebulosa Hufnagel } \\
\text { "Crino setara" }\end{array}$ & Europe \\
& Epiglaea apicata Grote & Europe \\
& Etiella zinckenella Treischke & U. S. A. \\
& Laphygma exigua Hübner & Anatolia \\
& "Miselia tincta" & Europe \\
& Archips rosana Linné & Europe \\
cacoeciae Ferrière & Alabama argillacea Hübner & U. S. A. \\
& Autographa sp. & U. S. A. \\
& Heliothis armigera Hübner & U. S. $A$. \\
& Laphygma frugiperda Smith et Abbot & U. S. A. \\
& Plathypena scabra Fabricius & U. S. A. \\
& Prodenia ornithogalli Guénée & U. S. A.
\end{tabular}




\begin{tabular}{|c|c|c|}
\hline \multirow[b]{2}{*}{ ceylonensis Howard } & Trichoplusia ni Hübner & U. S. A. \\
\hline & Euproctis fraterna Moore & Ceylon \\
\hline \multirow{5}{*}{ comstocki Howard } & Euproctis flava Bremer & Ceylon \\
\hline & Nygmia scintillans Walker & Malaya \\
\hline & Alabama argillacea Hübner & U. S. A. \\
\hline & Autographa sp. & U. S. A. \\
\hline & Caradrina sp. & U. S. A. \\
\hline & Heliothis armigera Hübner & U. S. A. \\
\hline & Laphygma frugiperda Smith et Abbot. & $\begin{array}{l}\text { Puerto Rico, } \\
\text { Trinidad }\end{array}$ \\
\hline & Plathypena scabra Fabricius & U. S. A. \\
\hline & Trichoplusia ni Hübner & U. S. A. \\
\hline epiplemae Ferrière & Fpiplema dohertyi Warren & Africa \\
\hline \multirow[t]{2}{*}{ euplexiae Rohwer } & Perigea capensis Guénée & India \\
\hline & Selepa docilis Butler & India \\
\hline \multirow{14}{*}{$\begin{array}{l}\text { frontalis Howard } \\
\text { fukaii Crawford } \\
\text { furnius Walker } \\
\text { gopimohai Mani } \\
\text { howardi Olliff } \\
\text { junctus Gahan } \\
\text { kuwanae Crawford } \\
\text { laphygmae Ferrière }\end{array}$} & Amathes c-nigrum Linné & U. S. A. \\
\hline & Naranga aenescens Moore & Japan \\
\hline & Protoparce cingulata Fabricius & Barbados \\
\hline & Laphygma exigua Hübner & India \\
\hline & Phragmatiphila truncata Walker & Australia \\
\hline & Isoparce cupressi Boisduval & U. S. A. \\
\hline & Parnara guttata Bremer et Grey & Japan \\
\hline & Amsacta moloneyi Druce & Africa \\
\hline & Heliothis sp. & Africa \\
\hline & Laphygma exempta Walker & Africa \\
\hline & Laphygma exigua Hübner & Africa \\
\hline & Leucania obsoleta Fabricius & Africa \\
\hline & Phytometra gamma Linné & Africa \\
\hline & Plusia orichalcea Fabricius & Africa. \\
\hline leonae Risbec & Anomis leona Schaus & Africa \\
\hline \multirow[t]{2}{*}{ leucostomus Rohwer } & Achaea janata Linné & India \\
\hline & 'Trabala vishnu Lefebvre? & India \\
\hline \multirow{4}{*}{$\begin{array}{l}\text { liparidis Ferrière } \\
\text { manilae Ashmead }\end{array}$} & Lymantria dispar Linné & Africa \\
\hline & Anomis sp. & Philippines \\
\hline & Cosmophila sp. & Philippines \\
\hline & Papilio alphenor Cramer & Philippines \\
\hline \multirow[t]{2}{*}{ maternus Bhatnagar } & Orthreis fullonica Linné & India \\
\hline & Orthreis materna Linné & India \\
\hline \multirow[t]{2}{*}{ mellipes Provancher } & Coleophora laricella Hübner & Canada \\
\hline & Feralia jocosa Guénée & Canada \\
\hline
\end{tabular}




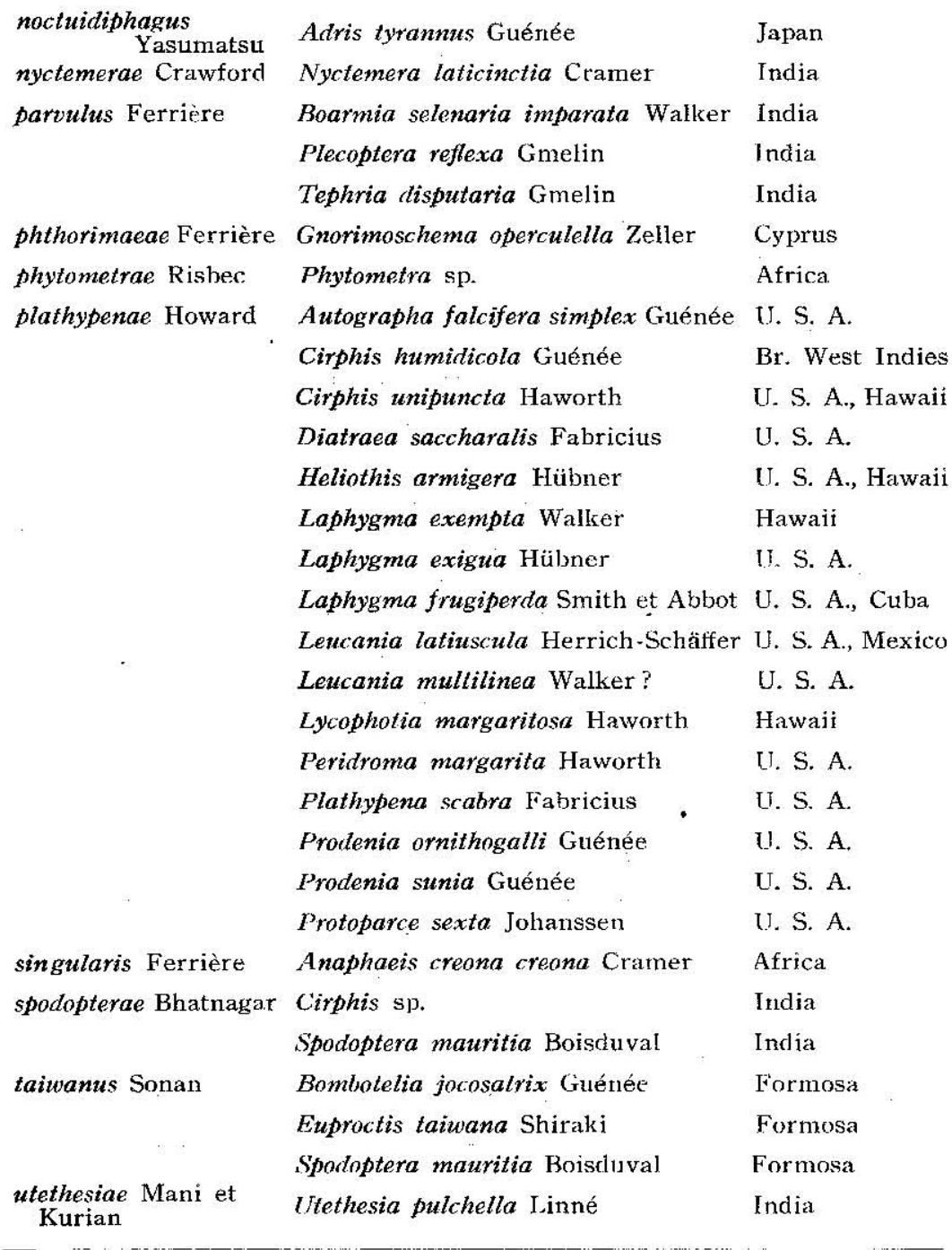

